\title{
Kompetensi guru pendidikan jasmani SMA bersertifikasi tahun 2009-2010 dalam pembelajaran pendidikan jasmani
}

\author{
Aditya Yan Saputro \\ SMP Muhammadiyah 3 Yogyakarta. Jl. Kapten Piere Tendean No.19, Wirobrajan, Kota \\ Yogyakarta, Daerah Istimewa Yogyakarta 55252 \\ Email: yansaradit@gmail.com
}

\begin{abstract}
Abstrak
Tujuan penelitian ini untuk mengetahui bagaimana kompetensi guru penjas SMA bersertifikasi tahun 2009-2010 dalam pembelajaran penjas di Daerah Istimewa Yogyakarta. Penelitian ini merupakan penelitian survey, penelitian ini menekankan pada kompetensi guru, yaitu kepribadian, profesional, pedagogik, dan sosial melalui penilaian diri sendiri, penilaian teman sejawat, penilaian siswa dan penilaian kepala sekolah. Subjek penelitian guru penjas SMA di Daerah Istimewa Yogyakarta yang sudah mendapatkan sertifikat pendidik dan sudah menerima tunjangan profesional pada tahun 2009-2010 berjumlah 45 guru dibagi menjadi dua kelompok: 20 guru untuk uji coba instrument dan 25 guru untuk pengambilan data penelitian. Teknik pengumpulan data dilakukan dengan menggunakan lembar angket, review dokumen serta dokumentasi. Hasil penelitian menunjukan bahwa secara keseluruhan kompetensi yang ditampilkan guru penjas SMA bersertifikasi tahun 2009-2010 di DIY dalam pembelajaran penjas sangat baik berdasarkan (a) penilaian kompetensi kepribadian menurut penilaian diri (76\%), teman sejawat $(80 \%)$, siswa $(52 \%)$, kepala sekolah $(72 \%)$. (b) penilaian kompetensi profesional menurut penilaian diri $(64 \%)$, teman sejawat $(60 \%)$, siswa $(52 \%)$, kepala sekolah $(52 \%)$. (c) penilaian kompetensi pedagogik menurut penilaian diri (64\%), teman sejawat $(60 \%)$, siswa $(44 \%)$, kepala sekolah $(56 \%)$. (d) penilaian kompetensi sosisl menurut penilaian diri $(52 \%)$, teman sejawat $(76 \%)$, siswa (48\%), kepala sekolah (68\%). Disarankan guru penjas untuk dapat meningkatkan diri serta mengembangkan diri sesuai dengan perkembangan zaman.
\end{abstract}

Kata kunci: Kompetensi Guru

\section{Teacher's competence physical education in senior high school certified 2009-2010 learning physical education}

\begin{abstract}
The main of the research is to find out how the competence of certified high school physical education teacher in 2009-2010 in teaching physical education in Yogyakarta. This research is an survey study, this study emphasizes the competence of teachers, namely personality, professional, pedagogical, and social through self-assessment, peer assessment, student assessment and evaluation of principals. Research subjects high school physical education teacher in Yogyakarta who have received teaching certificate and have received professional allowances in the year 2009-2010 amounted to 45 teachers were divided into two groups: 20 teachers to the test instrument and 25 teachers for research data collection. Techniques of data collection is done by using the sheet questionnaires, review of documents as well as documentation. The study results show that the overall competence displayed certified high school physical education teacher in 2009-2010 in DIY in excellent physical education teaching is based on (a) the assessment of competence according to self-assessments of personality (76\%), colleagues (80\%), students (52\%), principals (72\%). (b) an assessment of professional competence by self-assessment (64\%), colleagues (60\%), students (52\%), principals (52\%). (c) assessment of pedagogical competence by self-assessment (64\%), colleagues (60\%), students (44\%), principals (56\%). (d) assessment of competence sosisl by
\end{abstract}




\section{Jurnal Pendidikan Jasmani Indonesia, 14 (2), 2018- 70}

Aditya Yan Saputro

self-assessment (52\%), colleagues (76\%), students (48\%), principals (68\%). Suggested physical education teachers to improve themselves and development in the society.

Keywords: Teacher Competence

\section{PENDAHULUAN}

Pendidikan merupakan faktor utama dalam pembentukan pribadi manusia. Pendidikan sangat berperan dalam membentuk baik atau buruknya pribadi manusia. Pendidikan berperan penting dalam mengubah atau membentuk karakter dan watak manusia agar menjadi lebih baik. Dengan menerapkan sistem pendidikan yang bermutu dan didukung oleh guru yang profesional dan berkompeten dalam dunia pendidikan.

Menanggapi hal tersebut, pemerintah melalui depdiknas secara berangsur-angsur melakukan upaya untuk memperbaiki kualitas pendidikan di Indonesia. Dan salah satu upaya yang masih hangat dalam ingatan kita adalah sertifikasi guru. Sasaran program sertifikasi guru ini adalah semua guru yang telah memenuhi persyaratan kualifikasi akademik sebagaimana diatur dalam Undang-undang Guru dan Dosen Pasal 9, dan PP Nomor 19 Tahun 2005 Pasal 28 ayat 2 yaitu minimal sarjana atau diploma empat (S1/D-IV) yang dibuktikan dengan ijazah atau sertifikat keahlian yang relevan. Artinya, guru dengan kualifikasi dibawah S1 Atau D4 tidak dapat disertifikasi.

Guru memegang peranan penting dalam proses belajar mengajar, dalam proses pembentukan watak dan karakter anak didiknya. Karena itu dibutuhkan guru yang tidak hanya pandai dalam mengajar tetapi juga berkompeten dalam bidangnya. Guru sebagai pengemban profesi, secara holistik berada pada tingkatan tertinggi dalam sistem pendidikan nasional karena guru dalam melaksanakan tugas profesionalnya memiliki otonomi yang kuat. Di sisi lain, tugas guru sangat banyak, baik yang terkait dengan kedinasan maupun profesinya di sekolah, seperti mengajar dan membimbing para muridnya, memberikan penilaian hasil belajar peserta didiknya, mempersiapkan administrasi pembelajaran yang diperlukan, dan kegiatan lain yang berkaitan dengan pembelajaran. Hal ini menunjukan bahwa keprofesionalan dan kompetensi guru sangatlah diperlukan guna mencapai keberhasilan pendidikan. Program sertfifikasi guru sebagai salah satu cara yang digunakan pemerintah untuk meningkatkan kualitas guru agar tercapainya keberhasilan pendidikan di indonesia.

Guru yang telah mendapatkan sertifikat pendidik, setelah melalui berbagai rangkaian tahapan untuk mendaptkan sertifikat tersebut diharapkan akan memiliki kompetensi dan profesionalitas untuk dapat meningkatkan mutu kualitas pendidikan yang ada di Indonesia. Dengan kompetensi profesional, guru akan tampil sebagai pembimbing (councelor), pelatih (coach), dan manager pembelajaran (learning manager) yang mampu berinteraksi dengan siswa dalam proses transfer pengetahuan, ketrampilan, dan nilai-nilai yang baik. Semangat untuk tetap belajar (bukan hanya mengajar) akan membantu guru untuk mengupgrade pengetahuannya, sehingga dapat menyiasati kemajuan ilmu pengetahuan dan teknologi, serta peluang pemanfaatannya untuk memajukan proses belajar mengajar dikelas maupun dilapangan. Tanpa ada kinerja guru yang berkualitas, semua upaya untuk membenahi pendidikan akan kandas. Kurikulum yang baik, perpustakaan yang lengkap, laboratorium yang canggih, ketersediaan komputer dan internet nyaris tidak ada artinya untuk memperbaiki mutu pendidikan bila guru-gurunya tidak bermutu dan tidak mencintai profesinya (Wisudo dan Permanasari, Kompas 21/02/2006). Setelah guru dinyatakan lulus sertifikasi dan dibayar tunjangan profesinya maka secara teori kinerja guru tersebut akan membaik. Namun, tidak ada suatu jaminan bahwa jika seorang guru sudah mendapatkan tambahan penghasilannya lantas serta merta kinerjanya tinggi.

Lebih mencenangkan lagi apabila kita menilik kepada guru pendidikan jasmani, peniliti melihat adanya sinyal dan kesan negatif dari masyarakat awam tentang guru pendidikan jasmani seperti; kurang siapnya guru pendidikan jasmani dalam melaksanakan tugas dan jabatannya sebagai guru pendidikan jasmani, kurang kreatif untuk terus meningkatkan kemampuan kompetensinya, dalam mengajar tidak membuat rancangan pembelajaran, mengajar praktik tidak mengenakan pakaian olahraga, membiarkan siswa di lapangan dan 
guru duduk di tepi lapangan, melakukan evaluasi pendidikan jasmani disamakan dengan mengevaluasi olahraga. Gaya mengajar yang dilakukan oleh guru dalam praktik pendidikan jasmani yang cenderung masih tradisional, metode-metode praktik dipusatkan pada guru (teacher centered), dengan cara siswa melakukan latihan fisik berdasarkan perintah yang dilakukan oleh guru. Menanggapi hal tersebut peniliti melihat uji coba yang dilakukan oleh Aris mahasiswa FIK prodi PJKR di kota yogya secara keilmiahannya uji coba tersebut mempunyai tingkat validitas masih rendah, sehingga harus dilakukan penelitian yang bisa dipertanggung jawabkan secara ilmiah.

Terkait dengan permasalahan tersebut munculah pemikiran penulis bahwa kompetensi guru sangat berperan dalam proses pembelajaran, sehingga peneliti merasa tertarik untuk melakukan penelitian mengenai "Kompetensi Guru Penjas SMA Bersertifikasi tahun 2092010 dalam Pembelajaran Penjas di DIY"

\section{METODE}

Penelitian ini adalah penelitian survey. Penelitian survey yang dilakukan terhadap 45 guru penjas di 5 Kabupaten se-Daerah Istimewa Yogyakarta. Penelitian ini menggunakan desain survey. Oleh karena itu dalam penelitian ini tidak dilakukan apapun terhadap responden penelitian. Responden cukup diminta memberikan respon terhadap berbagai fenomena yang berkaitan dengan kompetensi guru tanpa memanipulasi terhadap variabel penelitian.

Subjek penelitian adalah guru-guru penjas SMA yang ada di Daerah Istimewa Yogyakarta yang berjumlah 45 guru yang dibagi menjadi dua yaitu : 20 guru untuk uji coba instrument dan 25 guru untuk pengambilan data.

Penelitian ini dilaksanakan di Sekolah Menengah Atas di Daerah Istimewa Yogyakarta. Sedangkan waktu pelaksanaan penelitian dilakukan pada bulan Agustus 2014 sampai bulan Desember 2014.

Populasi penelitian ini adalah guru-guru penjas SMA bersertifikasi yang ada di Daerah Istimewa Yogyakarta. Sampel penelitian yang diambil dengan cara sampel purposive, yaitu diujikan pada 45 guru penjas yang sudah mendapatkan sertifikat pendidik dan sudah menerima tunjangan profesional pada tahun 2009-2010.

Data dikumpulkan melalui angket dan juga cetakan dokumen serta documentasi. Penjabarannya sebagai berikut: (a) angket digunakan untuk mengetahui penilaian diri, kompetensi paedagogik, professional, kepribadian, dan social; (b) review dokumen untuk mengetahui kemampuan guru dalam membuat persiapan (RPP); (c) kuesioner untuk mengetahui pendapat guru; dan (d) dokumentasi untuk bukti dalam pelaksanaan pembelajaran.

Instrument yang digunakan dalam penelitian ini adalah (a) instrument pertama adalah lembar angket berupa penilaian diri meliputi aspek paedagogik, kepribadian, professional, dan social dan (b) instrument yang ketiga review dokumen persiapan pembelajaran yang dibuat guru/RPP.

Langkah-langkah dalam penelitian ini melalui beberapa tahap, tahap pendahuluan pada awalnya peneliti melakukan studi lapang untuk survey mengenai masalah yang terjadi. Hasil survey selanjutnya dianalisis dan dideskripsikan. Kemudian tahap penyusunan instrument dengan melihat hasil yang diperoleh pada studi pendahuluan, peneliti kemudian menyusun rancangan instrument untuk pengumpulan data, baik melalui kuesioner maupun review dokumen setelah tahap validasi instrument yang membuat rancangan instrument yang sudah disusun kemudian divalidasi konten lewat pakar, selanjutnya perbaikan dari instrument kemudian dipakai untuk mengambil data. Reliabilitas instrument di cari dengan Alfa Chronbach dan terakhir tahap pengumpulan data yang selanjutnya instrument yang valid dan andal digunakan untuk pengumpulan data.

Dalam penelitian ini, analisis data yang digunakan adalah: (1)Analisis diskriptif, yaitu analisis statistik yang digunakan untuk menggambarkan data yang terkumpul sebagaimana adanya tanpa bermaksud membuat kesimpulan untuk digeneralisasikan. Analisis ini berbentuk penyajian data dalam bentuk table, grafik, perhitungan persentase dan lain-lain. (2) Validitas dan reliabilitas, untuk mengukur validitas dan reliabilitas instrument, digunakan 
validitas konten/isi dan untuk reliabilitas instrument digunakan Alpha Cronbach. (3) Untuk menentukan tingkat kecenderungan seberapa baikkah kinerja guru penjas SMA dilakukan dengan melakukan kategorisasi tingkat kecenderungan pada variable. Karena itu perlu ditentukan dahulu mean ideal (MI), simpangan baku ideal (SBi) serta skor tertinggi ideal dan skor terendah ideal masing-masing sub variable sebagai kriteria. Perhitungan mean ideal, simpangan baku ideal menurut Sukardjo (2009:101) adalah sebagai berikut:

Mean ideal $(\mathrm{MI})=1 / 2 \times$ (skor tertinggi ideal+skor terendah ideal) Simpangan Baku ideal $=1 / 6$ (skor tertinggi ideal-skor terendah ideal) Skor tertinggi ideal $=\sum$ butir kriteria $\mathrm{x}$ skor tertinggi Skor terendah ideal $=\sum$ butir kriteria $x$ skor terendah Tingkat kecenderungan dibagi dalam lima kategori seperti tampak pada tabel .

Tabel 1. Kategori tingkat kecenderungan pada variable

\begin{tabular}{cc}
\hline Skor & Kriteria \\
\hline $\mathrm{i}+1,80 \mathrm{Sbi}$ & Sangat baik \\
$\mathrm{i}+0,08 \mathrm{SBi}<\mathrm{X} \leq \mathrm{i}+1,80 \mathrm{Sbi}$ & Baik \\
$\mathrm{i}-0,60 \mathrm{SBi}<\mathrm{X} \leq \mathrm{i}+0,60 \mathrm{Sbi}$ & Sedang/cukup \\
$\mathrm{i}-1,80 \mathrm{SBi}<\mathrm{X} \leq \mathrm{i}-0,60 \mathrm{Sbi}$ & Kurang \\
$\mathrm{i}-1,80 \mathrm{Sbi}$ & Sangat kurang \\
\hline
\end{tabular}

Skor tertinggi ideal adalah skor tertinggi yang mungkin diperoleh subjek dari keseluruhan pilihan alternative jawaban instrument penelitian.Skor terendah ideal adalah skor terendah yang mungkin diperoleh subjek dari keseluruhan pilihan alternative jawaban instrument penelitian.Selanjutnya dari analisis data kemudian disusun skor kategori komponen untuk mengetahui kecenderungan kategori sangat baik, baik, sedang/cukup, kurang atau sangat kurang.

Untuk mengetahui seberapa besar pengaruh motivasi terhadap kinerja atau sumbangan motivasi terhadap kinerja digunakan rumus koefisiensi determinan, koefisiensi determinan adalah kuadrat dari koefisiensi korelasi dikalikan 100\%. KD $=\quad x 100 \%$ dengan

$\mathrm{KD}=$ koefisien determinan; $r=$ koefisien korelasi. Korelasi pearson product moment yang digunakan untuk mengetahui seberapa besar pengaruh $\mathrm{X}$ terhadap $\mathrm{y}$, diolah dengan menggunakan SPSS (Statistical Product and Service Solution).untuk melakukan teknik regresi linear, yaitu kinerja $(y)$ dan motivasi $(x)$ (Sugiyono,2010, P.231). Uji Linieritas, digunakan uji F. uji Hipotesis, digunakan uji F, t, , dengan hipotesis Ho: regresi liniear; Ha:

regresi non linear.

Kriteria: Tolak hipotesis nol jika $\mathrm{F}$ hitung $>\mathrm{F}$ tabel.

\section{HASIL DAN PEMBAHASAN}

Deskripsi data merupakan gambaran umum mengenai masing-masing variabel sebagai pendukung dalam pembahasan berikutnya. Melalui gambaran umum ini akan tampak nilai kompetensi dengan indikator kepribadian, profesional, pedagogik, dan sosial dari penilaian diri sendiri, teman sejawat, dan penilaian dari siswa dari setiap indikator variabel yang diteliti. Selain itu juga terdapat data untuk mengukur motivasi guru dan kinerja yang dinilai oleh kepala sekolah kepada guru penjas SMA yang sudah mendapatkan sertifikat pendidik dan sudah menerima tunjangan profesional pada tahun 2009-2010.

Untuk menentukan tingkat kecenderungan seberapa baikkah kinerja guru penjas SMA dilakukan dengan melakukan kategorisasi tingkat kecenderungan pada variabel. Karena itu perlu ditentukan dahulu mean ideal (MI), simpangan baku ideal (SBi) serta skor tertinggi 
ideal dan skor terendah ideal masing-masing sub variabel sebagai kriteria. Perhitungan mean ideal, simpangan baku ideal menurut Sukardjo (2009, P.101) adalah sebagai berikut.

$\mathrm{X} \mathrm{i}=$ rerata skor ideal; nilai maksimal $=5$, minimal $=1=1 / 2(5+1)=3$

$\mathrm{SBi}=$ simpangan baku skor ideal;

$=1 / 6(5-1)=4 / 6=0,67$

Tabel 2. Konversi skor menjadi skala 5 untuk kompetensi Kepribadian, Profesional,

Pedagogik dan Sosial

\begin{tabular}{cc}
\hline Skor & Nilai Sebutan \\
\hline$X>4,206$ & Sangat Baik \\
$3,402<X \leq 4,206$ & Baik \\
$2,598<X \leq 3,402$ & Sedang \\
$1,794<X \leq 2,598$ & Kurang \\
$X \leq 1,794$ & Sangat Kurang \\
\hline
\end{tabular}

Batas-batas interval untuk mencari kategori dari hasil penelitian didapatkan data sebagai berikut :

Kompetensi Kepribadian

Hasil angket penilaian diri untuk kompetensi aspek kepribadian, dengan reliabilitas 0,777 dan validitas lebih dari 0,530 untuk taraf kepercayaan 99\%, didapatkan data seperti pada lampiran. Hasil perhitungan kategori kompetensi kepribadian yang ditinjau dari peneliti sendiri, teman sejawat, dan penilaian dari siswa dapat disajikan pada tabel sebagai berikut;

Tabel 3. Kategori Kompetensi Kepribadian Guru Penjas SMA se-Provinsi Daerah Istimewa Yogyakarta

\begin{tabular}{clcccc}
\hline Interval & \multicolumn{1}{c}{ Kategori } & Diri sendiri & Teman & Siswa & Kepala Sekolah \\
\hline$X>4,20$ & Sangat Baik & 19 & 20 & 13 & 18 \\
$3,40<X \leq 4,20$ & Baik & 6 & 5 & 12 & 5 \\
$2,59<X \leq 3,40$ & Sedang & 0 & 0 & 0 & 2 \\
$1,79<X \leq 2,59$ & Kurang & 0 & 0 & 0 & 0 \\
$X \leq 1,79$ & Sangat Kurang & 0 & 0 & 0 & 0 \\
& Total & 25 & 25 & 25 & 25 \\
\hline
\end{tabular}

Sumber; hasil olah data primer 2015

Berdasarkan hasil perhitungan kategori kompetensi kepribadian dari penilaian diri sendiri menunjukkan hasil sebesar 6 orang (24\%) dengan kategori baik, dan sebanyak 19 (76\%) orang dengan kategori Sangat Baik, sedangkan lainnya tidak ada yang kategori sangat kurang sampai sedang.

Hasil penilaian kompetensi aspek kepribadian guru Penjas SMA se-Provinsi Daerah Istimewa Yogyakarta dari teman sejawat untuk aspek kepribadian dapat dilihat hasil 5 orang (20\%) menyatakan kepribadian Baik, dan 20 orang (80\%) berkepribadian Sangat Baik, sedangkan lainnya tidak ada yang kategori sangat kurang sampai sedang.

Penilaian dari siswa untuk 25 guru, di dapatkan kategori bahwa kepribadian guru Penjas SMA di Daerah Istimewa Yogyakarta adalah Sangat Baik, yang dirinci 13 orang (52\%) Sangat Baik, 12 orang (48\%) Baik, dan tidak ada yang kategori sangat kurang sampai sedang.

Penilaian dari kepala sekolah, di dapatkan kategori bahwa kepribadian guru Penjas SMA di Daerah Istimewa Yogyakarta adalah Sangat Baik, yang dirinci 18 orang (72\%) 


\section{Jurnal Pendidikan Jasmani Indonesia, 14 (2), 2018- 74}

Aditya Yan Saputro

Sangat Baik, 5 orang (20\%) Baik 2 orang (8\%), dan tidak ada yang kategori sangat kurang dan kurang.

Penilaian secara keseluruhan diperoleh bahwa kategori kepribadian guru Penjas SMA di Daerah Istimewa Yogyakarta adalah sangat baik dengan jumlah 70 orang (70\%) Sangat Baik, 28 orang (28\%) Baik dan 2 orang (2\%) Sedang. Hasil perhitungan kategori kompetensi kepribadian dapat disimpulkan bahwa sebagian besar kompetensi dari aspek kepribadian dari semua penilaian sendiri, teman sejawat, siswa dan kepala sekolah menunjukkan kategori sangat baik. Kategori kompetensi aspek kepribadian dari semua penilaian dapat disajikan Gambar 1.

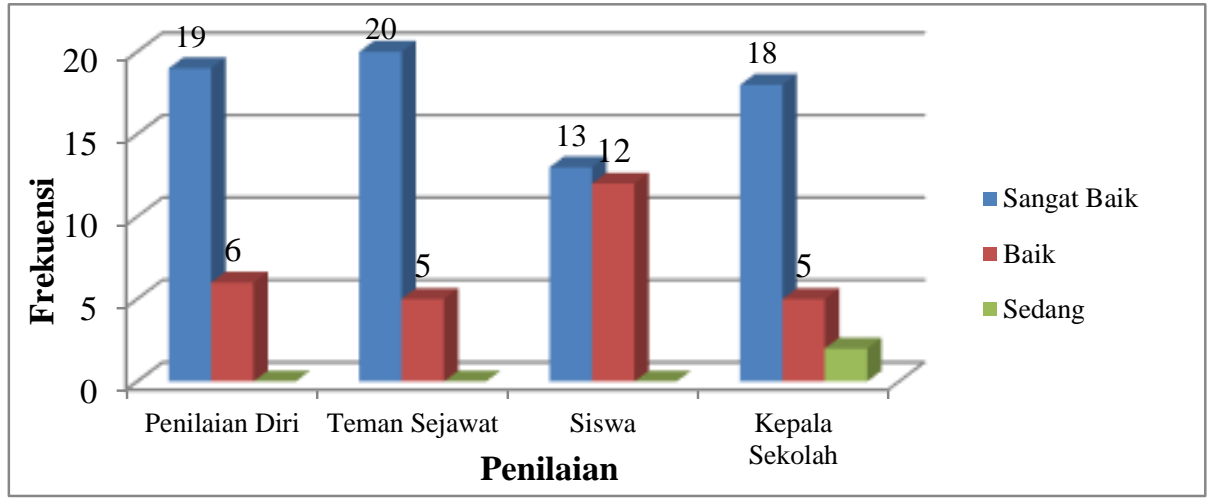

Gambar 1. Histogram Kompetensi kepribadian

Kompetensi Profesional

Kompetensi yang kedua dari aspek profesional yang terdiri dari 12 item soal. Hasil angket penilaian diri untuk kompetensi aspek profesional, dengan reliabilitas 0,894 dan validitas lebih dari 0,530 untuk taraf kepercayaan $99 \%$, didapatkan data seperti pada lampiran. Hasil perhitungan kategori kompetensi profesional yang ditinjau dari peneliti sendiri, teman sejawat, dan penilaian dari siswa dapat disajikan pada tabel sebagai berikut;

Tabel 4. Kategori Kompetensi Profesional guru Penjas SMA se-Provinsi Daerah Istimewa Yogyakarta

\begin{tabular}{clcccc}
\hline Interval & \multicolumn{1}{c}{ Kategori } & Diri sendiri & Teman & Siswa & Kepala Sekolah \\
\hline$X>4,20$ & Sangat Baik & 9 & 15 & 16 & 13 \\
$3,40<X \leq 4,20$ & Baik & 16 & 10 & 9 & 9 \\
$2,59<X \leq 3,40$ & Sedang & 0 & 0 & 0 & 3 \\
$1,79<X \leq 2,59$ & Kurang & 0 & 0 & 0 & 0 \\
$X \leq 1,79$ & Sangat Kurang & 0 & 0 & 0 & 0 \\
& Total & 25 & 25 & 25 & 25 \\
\hline
\end{tabular}

Sumber; hasil olah data primer 2015

Berdasarkan hasil perhitungan kategori kompetensi profesional dari penilaian diri sendiri menunjukkan hasil sebesar 16 orang (64\%) dengan kategori baik, dan sebanyak 9 (36\%) orang dengan kategori Sangat Baik, sedangkan lainnya tidak ada yang kategori sangat kurang sampai sedang.

Hasil penilaian kompetensi profesioanl guru Penjas SMA se-Provinsi Daerah Istimewa Yogyakarta dari teman sejawat untuk aspek profesional dapat dilihat hasil 10 orang (40\%) menyatakan profesional Baik, dan 15 orang (60\%) berprofesional Sangat Baik, sedangkan lainnya tidak ada yang kategori sangat kurang sampai sedang.

Penilaian dari siswa untuk 25 guru, di dapatkan kategori bahwa profesional guru Penjas SMA di Daerah Istimewa Yogyakarta adalah Sangat Baik, yang dirinci 16 orang (64\%) Sangat Baik, 9 orang (36\%) Baik, dan tidak ada yang kategori sangat kurang sampai sedang. 


\section{Jurnal Pendidikan Jasmani Indonesia, 14 (2), 2018- 75}

Aditya Yan Saputro

Penilaian dari kepala sekolah untuk 25 guru, di dapatkan kategori bahwa profesional guru Penjas SMA di Daerah Istimewa Yogyakarta adalah Sangat Baik, yang dirinci 13 orang $(52 \%)$ Sangat Baik, 9 orang (36\%) Baik, 3 orang (12\%) Sedang dan tidak ada yang kategori sangat kurang dan kurang.

Penilaian secara keseluruhan diperoleh bahwa kategori profesionalisme guru Penjas SMA di Daerah Istimewa Yogyakarta adalah sangat baik dengan jumlah 53 orang (53\%) Sangat Baik , 44 orang (44\%) Baik dan 3 orang (3\%) Sedang. Hasil perhitungan kategori kompetensi profesional dapat disimpulkan bahwa sebagian besar kompetensi dari aspek profesional dari semua penilaian sendiri, teman sejawat, siswa dan kepala sekolah menunjukkan kategori sangat baik. Kategori kompetensi aspek profesional dari semua penilaian dapat disajikan Gambar 2.

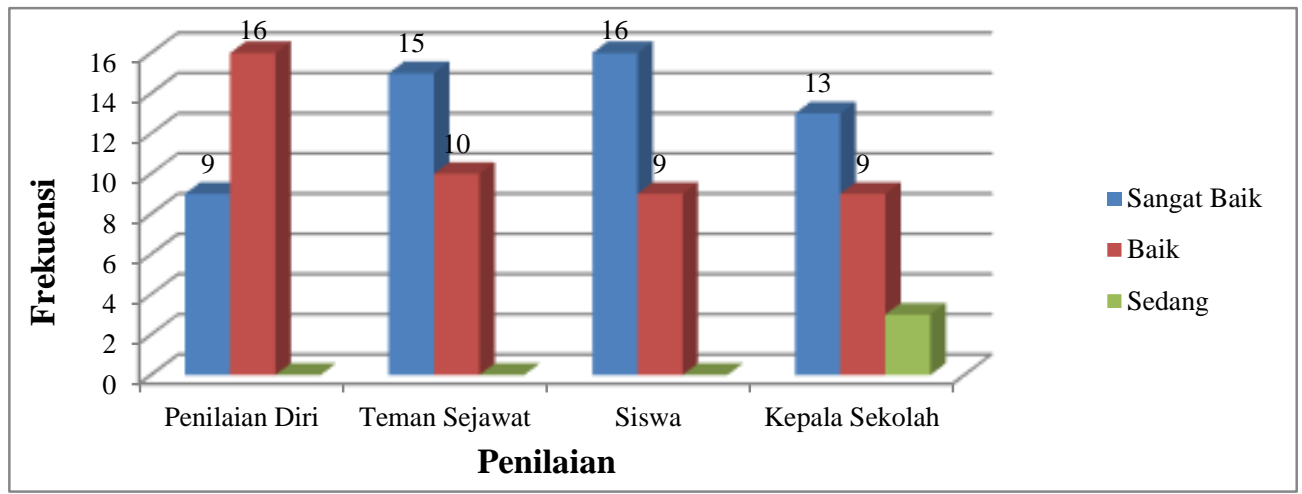

Gambar 2. Histogram Kompetensi profesional

Hasil histogram kompetensi profesional menunjukkan semua penilaian kategori sangat baik, jumlah frekuensi penilaian kometensi profesional dari diri sendiri dan siswa memiliki hasil yang sama yaitu 16 orang.

\section{Kompetensi Pedagogik}

Penilaian kompetensi pedagogik yang ditinjau dari peneliti sendiri, teman sejawat, dan penilaian dari siswa merupakan aspek kompetensi yang ketiga. Hasil angket penilaian diri untuk kompetensi aspek pedagogik, dengan reliabilitas 0,878 dan validitas lebih dari 0,530 untuk taraf kepercayaan $99 \%$, didapatkan data seperti pada lampiran. Hasil perhitungan kategori kompetensi pedagogik dapat disajikan pada tabel sebagai berikut;

Tabel 5. Kategori Kompetensi Pedagogik Guru Penjas SMA se-Provinsi Daerah Istimewa Yogyakarta

\begin{tabular}{clcccc}
\hline Interval & \multicolumn{1}{c}{ Kategori } & Diri sendiri & Teman & Siswa & Kepala Sekolah \\
\hline$X>4,20$ & Sangat Baik & 9 & 15 & 11 & 14 \\
$3,40<X \leq 4,20$ & Baik & 16 & 10 & 10 & 7 \\
$2,59<X \leq 3,40$ & Sedang & 0 & 0 & 4 & 4 \\
$1,79<X \leq 2,59$ & Kurang & 0 & 0 & 0 & 0 \\
$X \leq 1,79$ & Sangat Kurang & 0 & 0 & 0 & 0 \\
& Total & 25 & 25 & 25 & 25 \\
\hline
\end{tabular}

Sumber; hasil olah data primer 2015

Hasil perhitungan kategori kompetensi pedagogik dari penilaian diri sendiri menunjukkan hasil sebesar 16 orang (64\%) dengan kategori baik, dan sebanyak $9(36 \%)$ orang dengan kategori Sangat Baik, sedangkan lainnya tidak ada yang kategori sangat kurang sampai sedang. Penilaian kompetensi dari teman sejawat untuk aspek pedagogik dapat dilihat hasil 10 orang (40\%) menyatakan pedagogik Baik, dan 15 orang $(60 \%)$ berpedagogik Sangat Baik, sedangkan lainnya tidak ada yang kategori sangat kurang sampai sedang. 
Penilaian dari siswa untuk 25 guru, di dapatkan kategori bahwa pedagogik guru Penjas SMA di Daerah Istimewa Yogyakarta adalah Sangat Baik, yang dirinci 11 orang (44\%) Sangat Baik, 10 orang (40\%) Baik, kategori sedang sebanyak 4 orang (16\%), dan tidak ada yang kategori sangat kurang sampai kurang.

Penilaian dari kepala sekolah untuk 25 guru, di dapatkan kategori bahwa pedagogik guru Penjas SMA di Daerah Istimewa Yogyakarta adalah Sangat Baik, yang dirinci 14 orang (56\%) Sangat Baik, 7 orang (28\%) Baik, kategori sedang sebanyak 4 orang (16\%), dan tidak ada yang kategori sangat kurang sampai kurang.

Penilaian secara keseluruhan diperoleh bahwa kategori pedagogik guru Penjas SMA di Daerah Istimewa Yogyakarta adalah sangat baik dengan jumlah 49 orang (49\%) Sangat Baik , 43 orang (43\%) Baik dan 8 orang (8\%) Sedang. Sehingga dari hasil perhitungan kategori kompetensi pedagogik dapat disimpulkan bahwa sebagian besar kompetensi dari aspek pedagogik dari semua penilaian sendiri, teman sejawat, dan siswa menunjukkan kategori sangat baik. Kategori kompetensi aspek pedagogik dari semua penilaian dapat disajikan Gambar 3.

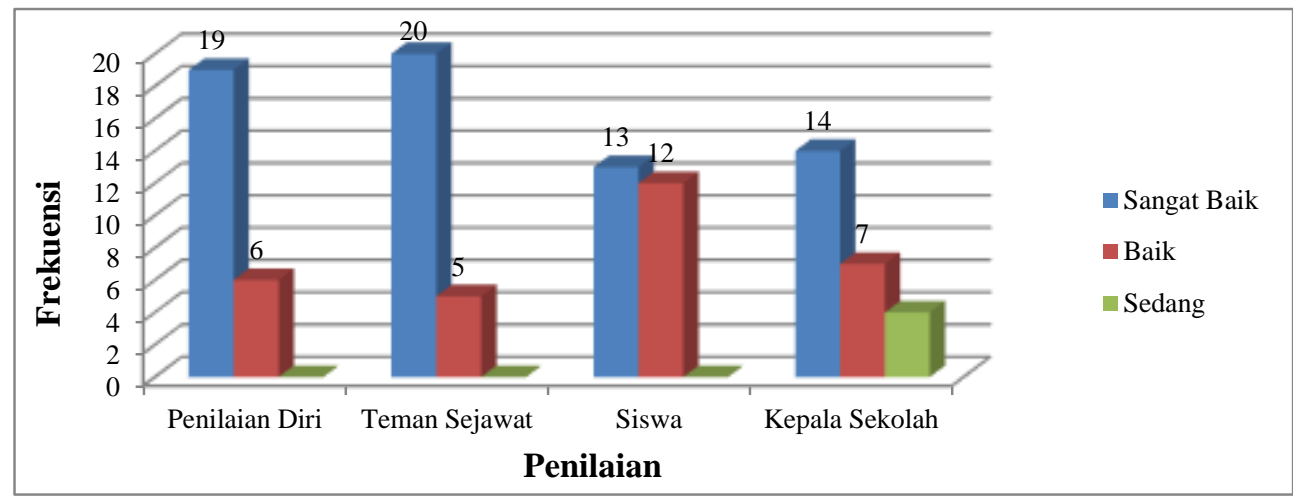

Gambar 3. Histogram Kompetensi pedagogik

Hasil histogram kompetensi pedagogik menunjukkan semua penilaian masuk dalam kategori sangat baik, jumlah frekuensi penilaian kompetensi pedagogik dari teman sejawat menilai paling tinggi, sedangkan paling rendah yaitu penilaian dari kepala sekolah namun masih dalam kategori sangat tinggi.

Kompetensi Sosial

Hasil angket kompetensi aspek sosial, dengan reliabilitas 0,884 dan validitas lebih dari 0,530 untuk taraf kepercayaan $99 \%$. Hasil perhitungan kategori kompetensi sosial yang ditinjau dari peneliti sendiri, teman sejawat, dan penilaian dari siswa dapat disajikan pada Tabel 6.

Tabel 6. Kategori Kompetensi Sosial Guru Penjas SMA se-Provinsi Daerah Istimewa Yogyakarta

\begin{tabular}{clcccc}
\hline Interval & \multicolumn{1}{c}{ Kategori } & Diri sendiri & Teman & Siswa & Kepala Sekolah \\
\hline$X>4,20$ & Sangat Baik & 13 & 19 & 12 & 17 \\
$3,40<X \leq 4,20$ & Baik & 12 & 6 & 5 & 6 \\
$2,59<X \leq 3,40$ & Sedang & 0 & 0 & 8 & 2 \\
$1,79<X \leq 2,59$ & Kurang & 0 & 0 & 0 & 0 \\
$X \leq 1,79$ & Sangat Kurang & 0 & 0 & 0 & 0 \\
& Total & 25 & 25 & 25 & 25 \\
\hline
\end{tabular}

Sumber; hasil olah data primer 2015

Berdasarkan hasil perhitungan kategori kompetensi sosial dari penilaian diri sendiri menunjukkan hasil sebesar 12 orang (48\%) dengan kategori baik, dan sebanyak 13 (52\%) orang dengan kategori Sangat Baik, sedangkan lainnya tidak ada yang kategori sangat kurang sampai sedang. Hasil penilaian kompetensi dari teman sejawat untuk aspek sosial 
dapat dilihat hasil 6 orang (20\%) menyatakan sosial Baik, dan 19 orang (80\%) bersosial Sangat Baik, sedangkan lainnya tidak ada yang kategori sangat kurang sampai sedang.

Penilaian dari siswa untuk 25 guru, di dapatkan kategori bahwa sosial guru Penjas SMA di Daerah Istimewa Yogyakarta adalah Sangat Baik, yang dirinci 12 orang (48\%) Sangat Baik, 5 orang (20\%) Baik, dalam kategori sedang sebanyak 8 orang (32\%), dan tidak ada yang kategori sangat kurang sampai kurang.

Penilaian dari kepala sekolah untuk 25 guru, di dapatkan kategori bahwa sosial guru Penjas SMA di Daerah Istimewa Yogyakarta adalah Sangat Baik, yang dirinci 17 orang (68\%) Sangat Baik, 6 orang (24\%) Baik, dalam kategori sedang sebanyak 2 orang (8\%).

Penilaian secara keseluruhan diperoleh bahwa kategori kompetensi sosial guru Penjas SMA di Daerah Istimewa Yogyakarta adalah sangat baik dengan jumlah 61 orang $(61 \%)$ Sangat Baik , 29 orang (29\%) Baik dan 10 orang (10\%) Sedang. Hasil perhitungan kategori kompetensi sosial dapat disimpulkan bahwa sebagian besar kompetensi dari aspek sosial dari semua penilaian sendiri, teman sejawat, siswa dan kepala sekolah menunjukkan kategori sangat baik. Kategori kompetensi sosial semua penilaian disajikan diagram berikut:

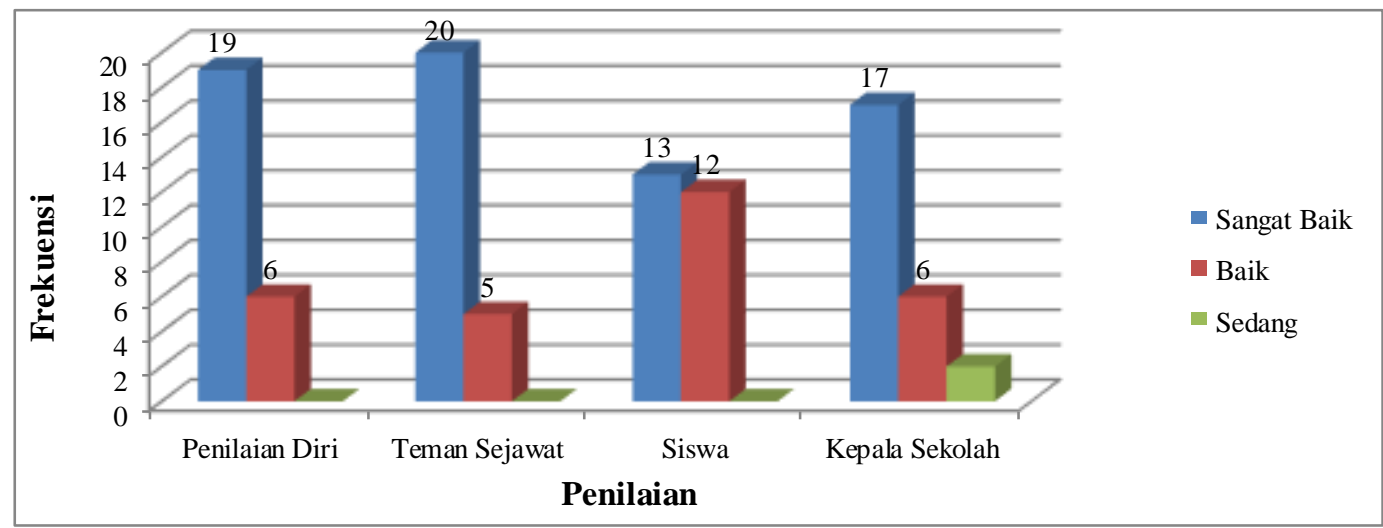

Gambar 5. Histogram Kompetensi sosial

Hasil histogram kompetensi sosial guru menunjukkan mayoritas penilaian masuk dalam kategori sangat baik, jumlah frekuensi penilaian kompetensi sosial guru dari teman sejawat menilai paling tinggi, sedangkan paling rendah yaitu penilaian dari siswa namun mayoritas masih dalam kategori sangat tinggi.

\section{Pembahasan}

\section{Penilaian Diri}

Kompetensi pendidikan yang terdiri dari aspek kepribadian, profesional, pedagogik, dan sosial yang dinilai dari sudut pandang penilaian diri, teman sejawat, dan penilaian siswa. Hasil penelitian evaluasi kinerja guru Penjas SMA bersertifikasi di DIY dalam mengembangkan nilai-nilai karakter semua aspek melalui pembelajaran penjas menunjukan hasil yang Sangat Baik. Sertifikasi guru merupakan proses pemberian sertifikat pendidik kepada guru. Sertifikat pendidik diberikan kepada guru yang telah memenuhi standar profesional guru. Guru Profesional merupakan syarat mutlak untuk menciptakan sistem dan praktik pendidikan yang berkualitas.

Hasil angket penilaian diri untuk kompetensi aspek kepribadian menunjukan hasil sebesar 6 orang (24\%) dengan kategori baik, hal ini dapat dilihat melalui penyampaian pembelajaran penjas dan sopan santun dalam semua kondisi dan situasi. Sedangkan 19 orang $(76 \%)$ dengan kategori Sangat Baik untuk aspek kepribadian berdasarkan penilaian diri, dapat dilihat melalui keseluruhan kepribadian baik itu penyampaian sesuatu kepada siswa, bersikap baik, bertutur kata yang baik, norma sopan santun yang baik dalam berkomunikasi dengan peserta didik, wali murid, sesama guru ataupun masyarakat sekitar, pengendalian diri yang bisa mencerminkan sebagai guru serta tak lupa bertanggung jawab berkomitmen tinggi sebagai guru profesional.

Secara keseluruhan kompetensi aspek kepribadian dari penilaian diri sendiri 


\section{Jurnal Pendidikan Jasmani Indonesia, 14 (2), 2018- 78}

Aditya Yan Saputro

menunjukkan hasil yang sangat baik, tetapi apabila diteliti lebih detail mengenai angket yang penilaianya masing dinilai perlu ditingkatkan lagi yaitu nomor satu mengenai guru berupaya maksimal untuk menyampaikan sesuatu apa adanya. Item keenam mengenai guru berusaha agar mampu mengendalikan diri dalam berbagai situasi dan kondisi. Nomor depalan yaitu guru berusaha memberikan kasih sayang yang sama pada semua siswa. Ketiga item ini yang perlu dimaksimalkan agar jawabannya lebih maksimal baik.

Kemudian penilaian diri dari kompetensi profesional menunjukan 16 orang (64\%) menyatakan Baik, dilihat melalui kegiatan pengembangan diri dengan meningkatkan pembelajaran yang baik, etos kerja yang tinggi, inovasi pengembangan dan pembuatan sarana untuk pembelajaran, kegiatan pengembangan diri materi diluar keolahragaan serta pembimbingan dan pendampingan siswa baik secara khusus di bidang keolahragaan ataupun pengawasan untuk materi mapel yang lain. Untuk yang 9 orang (36\%) menyatakan Sangat Baik, yang ditinjau dari kegiatan kepelatihan dan seminar yang secara umum memang tidak terlalu sering dan ada untuk keprofesionalan guru penjas dan pembuatan buku modul atau LKS.

Pada jawaban kompetensi aspek profesional item yang maish perlu ditingkatkan yaitu nomor tujuh mengani guru saya menggunakan bahan dari alam sekitar dalam pembelajaran. Kedua pada item nomor sepuluh guru berusaha untuk mengungkapkan ide dengan menggunakan bahasa yang baik dan benar. Ketiga nomor sebelas yaitu guru berminat dalam mengikuti kepelatihan atau seminar. Hasil jawaban setiap item tersebut masih minimal penilaiannya sangat setuju, untuk itu perlu ditingkatkan lagi.

Penilaiaan diri dari kompetensi pedagogik yang didapat 16 orang $(64 \%)$ menyatakan Baik dipandang melalui penerapan, pengaplikasian serta kelengkapan administrasi guru penjas khususnya RPP yang pelaksanaan pembelajarannya sudah sangat sesuai apalagi didalamnnya tertuang dan tersampaikan tentang pengembangan karakter, tak lepas juga tentang pemotivasian untuk ikut pembelajaran, pemanfaatan sarana dan prasarana pembelajaran, pengevaluasian, pemberian tugas, pengayaan dan selalu berinteraksi dengan peserta didik melalui sesi tanya jawab. Untuk 9 orang (36\%) Sangat Baik, hanya jarang melakukan remidial dan penggunaan sarpras yang kurang maksimal dikarenakan juga karena kondisi sekolah masing-masing yang berbeda.

Walaupun pada komponen pedagogik ini secara keseluruhan sudah sangat baik, tetapi ada item tertentu yang perlu ditingkatkan lagi yaitu nomor tiga yaitu guru berusaha melaksanakan pembelajaran sesuai dengan RPP dan mengenai tentang karakter. Kedua nomor item sembilan guru berusaha menanyakan kehadiran siswa. Ketiga nomor enam belas mengenai guru berusaha memulai pelajaran dengan menghubungkan pengetahuan yang dimiliki siswa. Guru lebih perhatian dengan siswa dengan selalu mengabsen kehadiran siswa agar guru lebih memiliki rasa kedekatan dengan siswa, selain itu pelajaran yang diberikan sesuai dengan tingkat pengetahuan siswa.

Penilaian diri kompetensi yang terakhir yaitu aspek sosial terdapat 13 orang (52\%) berpendapat Sangat Baik disebabkan karena seorang guru diharuskan memiliki interaksi yang sangat tinggi baik disekolah maupun diluar sekolah, berkomunikasi dengan masyarakat sekitar baik didekat lingkungan sekolah maupun lingkungan rumah sekitar, serta dapat menerima saran dan kritik dari berbagai pihak. Untuk yang 12 orang (48\%) berpendapat Baik melihat management waktu yang masih perlu di evaluasi diri sendiri karena padatnya kegiatan persekolahan masing-masing.

Item pertanyaan mengenai kompetensi pedagogik yang perlu ditingkatkan yaitu nomor sembilan mneganai guru berusaha berkomunikasi secara aktif dengan orang tua siswa. Kedua item nomor sepuluh yaitu guru berusaha memahami berbagai factor dari lingkungan yang mempengaruhi dan mendukung proses belajar mengajar. Ketiga nomor dua belas mengenai guru menyempatkan diri menghadiri kegiatan siswa diluar pelajaran yang saya ampu. Dengan kehadiran guru penjas pada saat kegiatan ekstrakulikuler di luar jam pelajaran, akan membuat siswa merasa ada perhatian dari guru, sehingga akan meningkatkan keprcayaan diri maupun kebanggaan dari siswa, kedekatan guru penjas dengan semua muridnya tentunya berdampak positif. 


\section{Jurnal Pendidikan Jasmani Indonesia, 14 (2), 2018- 79}

Aditya Yan Saputro

Teman Sejawat

Hasil penelitian evaluasi kinerja guru Penjas SMA Berserftifikasi di DIY dalam mengembangkan nilai-nilai karakter melalui pembelajaran penjas menunjukan hasil yang Sangat Baik, hal ini dapat dijabarkan melalui pembahasan di bawah ini.

Kompetensi kepribadian 20 orang (80\%) berkepribadian Sangat Baik, dilihat dari kemampuan guru dalam berpakaian, bertutur kata dalam mengendalikan diberbagai situasi manapun serta dapat memposisikan diri sebagai guru yang mampu beinteraksi dengan baik kepada khalayak umum. hasil 5 orang $(20 \%)$ menyatakan kepribadian Baik, berasumsi bahwa pengendalian diri sangat diperlukan agar dalam situasi apapun dapat mengontrol diri untuk senantiasa berperilaku dan bertutur kata yang baik.

Pada penilaian kompetensi aspek kepribadian ini item yang perlu ditingkatkan lagi yaitu nomor satu mengenai guru menyampaikan sesuatu apa adanya, kedua nomor delapan guru memberikan kasih sayang yang sama pada semua siswa. Ketiga nomor item sembilan guru mempunyai komitmen yang tinggi sebagai guru professional. Sikap guru harus mensampaikan sesuatu apa adanya kepada siswa ini melatih siswa juga untuk bersikap apa adnaya, selain itu guru dan siswa saling memneri kasih sayang, saling mengahormati, dna mengahrgai. Selanjutnya komitmen yang tinggi guru akan meningkatkan keprofesionalitas guru dalam mendidik siswa di sekolah.

Untuk kompetensi profesional dengan 15 orang (60\%) mengatakan Sangat Baik dikarenakan banyak beberapa teman guru melihat kinerja guru penjas tersebut memiliki etos kerja yang tinggi, berinteraksi tanpa membedakan serta dapat membantu dalam hal mendampingi atau mengawasi baik dalam akademik maupun non akademik. Kemudian 10 orang (40\%) berpendapat Baik, dengan pendapat teman guru sejawat bahwa guru penjas tidak hanya sekedar mengajar praktek dilapangan tetapi juga mengajarkan tentang teori dengan dibuktikannya adanya LKS atau modul penjas yang sudah beredar disekolahsekolah.

Item pertanyaan dalam angket kompetensi aspek profesional pada nomor enam yaitu guru mengadakan pembaharuan dalam pembelajaran. Nomor tujuh tentang guru menggunakan bahan dari alam sekitar dalam pembelajaran. Nomor dua belas yaitu guru membuat karya inovatif. Ketiga nomr item ini perlu ditingkatkan lebih maksimal oleh guru.

Kompetensi Pedagogik yang dimiliki guru penjas di DIY menurut 25 teman sejawat tergolong Sangat Baik (60\%) 15 orang mengemukakan bahwa guru penjas yang diamati memiliki kemampuan yang berinteraksi baik, penguasaan materi yang bagus dan mudah dipahami siswa, pemanfaatan sarpras yang maksimal sesuai dengan kemampuan sekolah serta model-model pembelajaran yang bervariatif. Kemudian untuk 10 orang (40\%) yang menyatakan Baik mengamati guru penjas yang selalu memotivasi siswanya dalam pembelajaran dan dapat memahami perbedaan masing-masing individu siswa.

Pada aspek pedagogik ini item yang perlu ditingkatkan oleh guru yaitu nomor dua belas yaitu guru melaksanakan program remedial dan pengayaan, hal ini dilakukan untuk meningkan nilai prestasi siswa. Item tiga belas guru mengaitkan pelajaran dengan situasi kehidupan nyata, agar siswa mudah melakukan pelajaran penjas guru dapat mengaplikasikan pelajaran dengan situasi kegidupan sehari-hari, seperti lari, jalan cepat, lempar, dan lainnya. dan item empat belas yaitu guru menggunakan strategi mengajar yang berbeda sesuai dengan materi pelajaran.

Untuk kompetensi sosial ini dengan 19 orang (76\%) berpendapat Sangat Baik, hal ini teman sejawat melihat kemampuan guru penjas yang mampu bersosialisasi dengan masyarakat sekitar sekolah dan beberapa wali murid yang ada disekolah, tak lebih halnya dalam membina siswa yang bermasalah. Dalam perbedaan keyakinan pun guru penjas sangat bertoleransi dalam bermasyarakat. Kategori baik sebanyak 6 orang (24\%) menganai kompetensi sosial yang dinilai teman sejawat.

Item soal pertnyaan yang perlu ditingkatkan lagi pada aspek sosial untuk penilaian teman sejawat nomor item tiga yaitu guru mampu menyampaikan pendapat, guru yang berani berpendapat juga akan melatih siswa untuk berani mengutarakan pendapat dan masukan Nomor sembilan berkomunikasi secara aktif dengan orang tua siswa, komunikasi sangat penting dalam segala urusan apalagi dalam proses belajar mengajar, agar siswa 


\section{Jurnal Pendidikan Jasmani Indonesia, 14 (2), 2018- 80}

Aditya Yan Saputro

paham dan mengerti apa yang dijelaskan guru. Nomor sebelas yaitu guru mengerti nilai-nilai dan norma-norma yang dijunjung tinggi oleh masyarakat, sebagai seorang guru penjas yang mendidik di sekolah juga tidak terlepas dengan norma yang dijunjung oleh masyarakat, guru dan siswa juga bagian dari masyarakat sendiri, sehingga perlu menjunjung tinggi nilai dan norma yang ada dimasyarakat.

Penilaian dari Siswa

Penilaian kompetensi dari sudut pandang yang ketiga dari siswa. Untuk penilaian dari siswa kompetensi kepribadian terdapat 13 orang (52\%) Sangat Baik, dengan pendapat siswa tentang perilaku kepribadian tentang ketaatan guru dalam menjalankan peraturan yang berlaku dan 12 orang (48\%) menyatakan Baik untuk guru dalam bersikap, bertutur kata serta berpakaian. Pada aspek ini item pertanyaan yang perlu ditingkatkan yaitu nomor dua yaitu guru menyampaikan ijin jika tidak dapat mengajar dengan alasan yang sebenarnya. Nomor tiga tentang guru menyampaikan permintaan maaf jika terlambat dilapangan. Sikap ini juga akan melatih siswa untuk melakukan hal yang sama apabila ijin masuk sekolah dan terlambat datang ke sekolah.

Kompetensi profesional terdiri dari 16 siswa (64\%) berkata Sangat Baik, dilihat dengan kehadiran guru yang tepat waktu, guru dapat menerima masukan dari siswa dan proses pembelajaran yang berjalan secara berurutan, 9 siswa $(36 \%)$ beranggapan Baik, melihat keaktifan seorang guru penjas dalam mendampingi, mengawasi dan membimbing siswa baik akademik maupun non akademik. Item pertanyaan pada aspek ini yang perlu ditingkatkan nomor dua yaitu guru memulai dan mengakhiri kegiatan dapat melihat kondisi siswa yang berganti pakaian dan beristirahat. Nomor tiga tentang guru dapat menerima masukan dari siswa. Seorang guru juga perlu menerima masukan dari siswa agar proses belajar mengajar lebih baik lagi, kebanyak guru yang berpikiran kolot tidak akan pernah mau mendengarkan masukan dari siswa, padahal masukan dari siswa yang di didik juga bisa menjadi evaluasi guru lebih baik.

Kemudian untuk kompetensi pedagogik menurut siswa terdapat 11 anak (44\%) berasumsi Sangat Baik. Guru penjas menurut siswa dalam mengajarkan pembelajaran penjas sangat terlihat pengembangan karakter didalam materi penjas, karena di dalam materi tersebut ranah afektif, sikap, tutur kata dan tingkah laku siswa sangat terlihat, selain itu guru juga mengembangkan kemampuan siswa khususnya didalam hal gerak atau psikomotorik yang bermanfaat sekali dalam kehidupan sehari-hari. Guru penjas selalu membangkitkan semangat anak-anak untuk mengikuti KBM Penjas, sehingga siswa-siswi sangat antusias dan merasa senang dengan pembelajaran tersebut, pembelajaran meliputi beberapa materi permainan, atletik, senam, kebugaran dan kesehatan bersifat sangat menyenangkan dan memiliki makna yang sangat berarti khususnya di pengembangan karakter. Guru penjas selain mengajarkan materi juga melakukan pendekatan pedagogik yang mendekati ke ranah afektif.

Siswa sebanyak 10 anak (40\%) mengatakan Baik dimana seorang guru penjas mempunyai kewajiban dalam hal administrasi yang harus tersedia sebelum pembelajaran berlangsung, seperti RPP yang didalamnya berisi tentang proses pembelajaran yang akan diajarkan ke siswa. Selain RPP guru juga harus mempersiapkan sarana dan prasarana yang ada sesuai dengan kemampuan sekolah, bahkan ada guru yang membuat, memodifikasi serta menginovasi sarana dan prasarana demi kelancaran KBM sesuai yang tertuang di RPP. Kemudian 4 anak (16\%) beranggapan Sedang, yang dalam kinerjanya seorang guru penjas pemanfaatan IT untuk proses pembelajaran khusunya materi kesehatan yang didalamnya berisi tentang teori kesehatan.

Terakhir untuk kompetensi Ssosial, 12 siswa (48\%) mengkategorikan Sangat Baik, yang dalam hubungannya seorang guru penjas memiliki kemampuan bersosialisasi baik dalam hal akademik maupun non akademik dan dengan wali siswa maupun masyarakat sekitar. Bagi sebagaian siswa mengganggap bahwa guru penjas juga bisa sebagai seorang konseling dimana selain tugasnya mengajar guru penjas juga dapat melakukan pendekatanpendekatan kepada siswa yang didalamnya banyak berisi motivasi, pengembangan minat dan pengembangan diri siswa dalam berbagai hal, ini terbukti disekolah-sekolah banyak 
guru penjas yang membantu tugas BK dalam menyelesaikan masalah-masalah pribadi siswa yang erat kaitannya dengan semangat siswa dalam mengikuti semua mapel disekolah.

Kategori aspek sosial selnajutnya sebanyak 5 siswa (20\%) menyatakan Baik, dalam memahami berbagai faktor dari lingkungan yang mempengaruhi dan mendukung proses pembelajaran serta dalam menerima saran dan kritik secara terbuka. Sedangkan 8 siswa (32\%) mengatakan Sedang, dalam memperlakukan siswa secara adil dalam suatu pembelajaran demi memotivasi siswa yang memiliki kemampuan psikomotoriknya kurang.

Penilaian Kepala Sekolah

Kompetensi kepribadian merupakan kompetensi yang harus dimiliki oleh seorang guru, karena guru sebagai tenaga pendidik yang tugas utamanya mengajar, memiliki karakteristik kepribadian yang sangat berpengaruh terhadap keberhasilan pengembangan sumber daya manusia. Kepribadian yang mantab dari sosok seorang guru akan memberikan teladan yang baik terhadap anak didik maupun masyarakatnya.

Pada kompetensi penilaian dari kepala sekolah terkait kepribadian guru Penjas SMA di Daerah Istimewa Yogyakarta adalah Sangat Baik, yang dirinci 18 orang (72\%) Sangat Baik, 5 orang (20\%) Baik 2 orang (8\%), dan tidak ada yang kategori sangat kurang dan kurang. Aspek yang mendapat penilaian terendah dari kompetensi kepribadian yaitu item ke-satu dan ke-empat dengan masing-masing rerata 4,32. Aspek ke-satu yaitu bapak/ibu penjas untuk menyampaikan sesuatu apa adanya. Aspek ke-empat yaitu bapak/ibu guru berpakaian rapi dan sopan. Hal ini menunjukkan bahwa pada kondisi tertentu guru penjas kurang berpakaian rapi dikarenakan sistem belajar guru penjas yaitu di luar kelas. Sehingga pada saat-saat tertentu kerapian guru dinilai kurang.

Kompetensi profesional adalah kemampuan penguasaan materi pelajaran secara luas dan mendalam. Kompetensi ini merupakan kompetensi yang sangat penting, karena langsung berhubungan dengan kinerja yang ditampilkan. Pada kompetensi profesional guru Penjas SMA di Daerah Istimewa Yogyakarta adalah Sangat Baik, yang dirinci 13 orang $(52 \%)$ Sangat Baik, 9 orang (36\%) Baik, 3 orang (12\%) Sedang dan tidak ada yang kategori sangat kurang dan kurang.

Aspek yang mendapat nilai rerata terendah yaitu item ke-sebelas yaitu bapak/ibu guru mempunyai minat dalam mengikuti kepelatihan atau seminar dengan rerata 3,72 . Hal ini dapat disebabkan karena pelatihan atau seminar membutuhkan waktu yang tidak sedikit. Sehingga perlu menyesuasikan dengan jadwal mengajar di sekolah. Aspek yang mendapat nilai tertinggi yaitu aspek pertama yaitu bapak/ibu guru melaksanakan tugas sesuai dengan ketentuan dengan rerata 4,56. Aspek ini menunjukkan secara umum kepala sekolah menilai guru penjas sudah dapat menjalankan apa yang menjadi tanggungjawab para guru penjas.

Kompetensi pedagogik adalah kemampuan mengelola pembelajaran peserta didik. Kompetensi ini dapat dilihat dari kemampuan merencanakan program pembelajaran, kemampuan melaksanakan interaksi atau mengelola proses pembelajaran, dan kemampuan mengelola penilaian. Pada kompetensi pedagogik guru Penjas SMA di Daerah Istimewa Yogyakarta adalah Sangat Baik, yang dirinci 14 orang (56\%) Sangat Baik, 7 orang (28\%) Baik, kategori sedang sebanyak 4 orang (16\%), dan tidak ada yang kategori sangat kurang sampai kurang. Aspek yang mendapat penilaian terendah yaitu aspek ke-dua belas (bapak/ibu guru melaksanakan program remedial dan pengayaan) dengan rerata 4,00. Aspek yang mendapat nilai tertinggi yaitu aspek ke-tujuh (bapak/ibu guru mengevaluasi hasil belajar siswa) dengan rerata 4,64.

Kompetensi sosial adalah kemampuan guru untuk berkomunikasi dan berinteraksi secara efektif dan efisien dengan peserta didik, sesama guru, orang tua/wali peserta didik, dan masyarakat sekitar. Di samping itu guru harus memiliki kemampuan berkomunikasi secara international, memiliki kemampuan menggunakan ICT mutakhir dan canggih. Tingkat kompetensi dapat menentukan keprofesionalan guru itu dalam melaksanakan tugas pekerjaannya.

Pada kompetensi sosial guru Penjas SMA di Daerah Istimewa Yogyakarta adalah Sangat Baik, yang dirinci 17 orang (68\%) Sangat Baik, 6 orang (24\%) Baik, dalam kategori sedang sebanyak 2 orang (8\%). Aspek yang mendapat penilaian tertinggi yaitu aspek ke- 
satu (bapak ibu guru terbuka dalam menerima kritik) dengan rerata 4,64.Aspek yang mendapat penilaian terendah yaitu item ke-delapan (bapak/ibu guru mempunyai interaksi yang baik dengan siswa) dengan rerata 4,00 . Hal ini dapat dikarenakan guru lebih menjaga kewibawaan sebagai guru sehingga mengurangi interaksi kepada siswa.

\section{SIMPULAN}

Hasil penelitian kompetensi guru penjas SMA bersertifikasi tahun 2009-2010 dalam pembelajaran penjas di DIY sebagai berikut: Pertama. Penilaian kompetensi kepribadian berdasarkan penilaian diri sendiri dengan persentase (76\%) sangat baik, teman sejawat $(80 \%)$ sangat baik, siswa $(52 \%)$ sangat baik dan kepala sekolah $(72 \%)$ sangat baik, guru penjas SMA di Daerah Istimewa Yogyakarta secara mayoritas masuk dalam kategori sangat baik. Kedua. Penilaian kompetensi profesionalisme berdasarkan penilaian diri sendiri dengan persentase (64\%) sangat baik, teman sejawat $(60 \%)$ sangat baik, siswa (52\%) sangat baik dan kepala sekolah (52\%) sangat baik, guru penjas SMA di Daerah Istimewa Yogyakarta secara mayoritas masuk dalam kategori sangat baik. Ketiga. Penilaian kompetensi pedagogik berdasarkan penilaian diri sendiri dengan persentase $(64 \%)$ baik, teman sejawat $(60 \%)$ sangat baik, siswa (44\%) sangat baik dan kepala sekolah $(56 \%)$ sangat baik, guru penjas SMA di Daerah Istimewa Yogyakarta secara mayoritas masuk dalam kategori sangat baik. Keempat. Penilaian kompetensi sosial berdasarkan penilaian diri sendiri dengan persentase (52\%) sangat baik, teman sejawat (76\%) sangat baik, siswa (48\%) sangat baik dan kepala sekolah (68\%) sangat baik, guru penjas SMA di Daerah Istimewa Yogyakarta secara mayoritas masuk dalam kategori sangat baik.

\section{DAFTAR PUSTAKA}

Majid Abdul, Andayani Dian. (2004). Pendidikan agama Islam berbasis kompetensi. Bandung: Remaja Rosdakarya.

Pathoni Achmad. (2007). Peran kiyai dalam politik. Yogyakarta: Pustaka Pelajar.

Mahendra Agus, M.A.(2005) Falsafah pendidikan jasmani. Departemen Pendidikan Nasional Direktorat Jenderal Pendidikan Dasar Dan Menengah Direktorat Pendidikan Luar Biasa. Bagian Proyek Pendidikan Kesehatan Jasmani

Pendidikan Luar Biasa.

Suryobroto S. Agus. (2004). Teknologi pembelajaran penjas Yogyakarta .FIK UNY YOGYAKARTA.

Badan Narkotika Nasional (BNN). Hasil survey nasional penyalahgunaan dan peredaran gelapnarkoba pada kelompok pelajar dan mahasiswa di 33 propinsi di Indonesia tahun 2006.

Baharuddin, H, Nurwahyuni. (2007). Teori belajar dan pembelajaran. Yogyakarta: Ar-Ruz Media.

Borg, W.R. Gall, M.D (1983). Educational researcher: An introduction Fourth edition. New York: Longman.

Buchory. (2008). Kiat sukses sertifikasi. Makalah: disampaikan pada seminar Nasional Pusat Studi Pendidikan IKA UNY.

Cohen, J. (2006). Social, emotional, ethnical and academic education: Creating climate for leraning, participation in democrazy and well being. Harvard Education Review, Vol. 71 No. 2 Summer 2006.

Departemen Pendidikan Nasional (2003). Undang-Undang No. 20 Tahun 2003 tentang sitem pendidikan nasional.

Mulyasa E. (2007). Standar kompetensi dan sertivikasi Guru. Bandung: Remaja Rosdakarya.

Wibowo Teguh Eri. (2012).Tingkat profesionalisme guru penjas se-Kabupaten Pemalang dalam pembelajaran penjas. Skripsi: Universitas Negeri Yogyakarta.

Hoetomo. (2005). Kamus Lengkap Bahasa Indonesia. Surabaya: Mitra Pelajar. 


\section{Jurnal Pendidikan Jasmani Indonesia, 14 (2), 2018- 83}

Aditya Yan Saputro

Wahyu Nur Furqan. (2011). Profesionalisme guru pendidikan jasmani SMU negeri seKabupaten sleman dalam pembelajaran penjas. Skripsi: Universitas Negeri Yogyakarta.

Anwar Idochi. (2006). Dasar-dasar statistika. Bandung: Alfabeta.

Wahyudi Imam. (2012). Mengejar profesionalisme guru. Jakarta: Prestasi Pustakaraya. Kemdikbud. (2010). Pemilihan Kepala Tk Berprestasi. Diakses dari http://prestasi.guruindonesia.net pada tanggal 15 April 2013.

Rusli Lutan. (2001). Pengukuran dan evaluasi pendidikan jasmani kesehatan. Bandung: DEPDIKBUD.

Rusli Lutan dan Suherman Adam. (2000). Pengukuran dan evaluasi pendidikan jasmani. Jakarta. Depdiknas.

Sudjana Nana. (2002). Dasar-dasar proses belajar-mengajar. Bandung: Sinar Baru Algensindo.

Hamalik Oemar. (2008). Proses belajar mengajar. Jakarta: PT Bumi Aksara.

Suhertian A Piet. (2004). Profil pendidik profesional. Yogyakarta: Andi Offset.

Sugiono. (2006). Metode penelitian bisnis. Alfabeta: Bandung.

Arikunto Suharsimi. (2008). Prosedur penelitian suatu pendekatan praktik. Jakarta: Rineka Cipta.

Arikunto Suharsimi. (2006). Prosedur penelitian suatu pendekatan praktik. Jakarta: Rineka Cipta.

Suherman, A. (2007). Teacher's curricullum value orientations dan implikasinya pada pengembangan kurikulum dan pembelajaran pendidikan jasmani. Disertasi. Bandung: Universitas Pendidikan Indonesia.

Suherman, A. (2006). Undang-undang guru Dan dosen: (UU RU No. 14 Th 2005) Jakarta: Sinar Grafika.

Winarmo M.E. (2008). Evaluasi dalam pendidikan jasmani dan olahraga. Malang:

YB Dwi Susanto. (1991). Penilaian kepala sekolah terhadap pelaksanaan tugas

profesi guru pendidikan jasmani dan kesehatan SMU Kodya Yogyakarta. Skripsi: Universitas Negeri Yogyakarta. 